\title{
The effects of prey availability on pup mortality and the timing of birth of South American sea lions (Otaria flavescens) in Peru
}

\author{
Karim H. Soto ${ }^{1,2 *}$, Andrew W. Trites ${ }^{1}$ and Milena Arias-Schreiber ${ }^{2}$ \\ ${ }^{1}$ Marine Mammal Research Unit, Fisheries Centre and Department of Zoology, University of British Columbia, 6248 Biological Sciences Rd., \\ Vancouver, British Columbia, Canada V6T 1Z4 \\ ${ }^{2}$ Instituto del Mar del Peru (IMARPE), Esquina de Gamarra y General Valle S/N Chucuito, Callao, Peru \\ (Accepted 5 May 2004)
}

\begin{abstract}
Pup mortality and the timing of birth of South American sea lions Otaria flavescens were investigated to determine the possible relationship between fluctuations in prey availability in the Peruvian upwelling ecosystem and current and future reproductive success of sea lions during six consecutive breeding seasons. Our study from 1997 to 2002 encompassed the strongest El Niño on record and one La Niña event. Pup mortality ranged from 13\% before El Niño to $100 \%$ during El Niño, and was negatively correlated with prey availability. Abortions were also more frequent when prey availability was low. However, pup mortality remained high following El Niño due to the punctuated short-term effects it had on population dynamics and subsequent maternal behaviour. Births occurred later in the season after years of low food availability and earlier following years of high food availability. The peak of pupping occurred around the peak of mortality in all years, and may have been the product of intensive competition between bulls at the peak of the breeding season. The stronger and more frequent El Niños that appear to be occurring along the Peruvian coast may produce significant stochastic changes in future births and pup mortality, which may place the vulnerable South American sea lion population in Peru at greater risk.
\end{abstract}

Key words: South American sea lion, Otaria flavescens, El Niño, La Niña, pup mortality, timing of birth, birth rates

\section{INTRODUCTION}

Changes in the abundance or availability of prey may shape breeding, maternal and survival strategies, and compromise the future reproductive success and population dynamics of their predators. Such changes have been noted among such species as Humboldt penguins Spheniscus humboldti (Paredes \& Zavalaga, 1998), southern fulmars Fulmarus glacialoides (Jenouvrier, Barbraud \& Weimerskirch, 2003), Galapagos fur seals Arctocephalus galapagoensis (Trillmich \& Ono, 1991), water rats Nectomys squamipes (Bergallo \& Magnusson, 1999), wild boars Sus scrofa (Massei, Genov \& Staines, 1996), and fat dormouse Myoxus glis (Bieber, 1998). Among pinnipeds, the effects of food shortage have been noted to increase the length of foraging trips taken by lactating females (Costa, Croxall \& Duck, 1989; Heath etal., 1991; Trillmich \& Ono, 1991; Lunn \& Boyd, 1993a; Boyd et al., 1994; McCafferty et al., 1998; Georges, Tremblay \& Guinet, 2000). They have also been seen to affect the timing of implantation (Boyd,

*All correspondence to: Karim H. Soto.

E-mail: soto@zoology.ubc.ca
1984; Boyd, 1996), decrease the growth rate of pups (Trillmich etal., 1991; Lunn, Boyd \& Croxall, 1994) and increase pup mortality (DeLong \& Antonelis, 1991; Francis \& Heath, 1991; Le Boeuf \& Reiter, 1991; Majluf, 1991; Trillmich \& Dellinger, 1991; Lunn \& Boyd, 1993a; Roux, 1997). Other effects of food shortage include reducing pup production, delaying the timing of births and extending the length of breeding cycles (Trillmich, 1985; Ono, Boness \& Oftedal, 1987; Lunn \& Boyd, 1993b; Boyd, 1996; Guinet et al., 1998; Pomeroy \& Duck, 2000; Trites \& Donnelly, 2003).

The Peruvian upwelling system is one of the most unpredictable productive marine ecosystems in the world. As a consequence, pinnipeds and sea birds inhabiting the Pacific coast have to endure inter-annual fluctuations of their food supply (Trillmich \& Ono, 1991). One of the largest but less understood predators in this ecosystem is the South American sea lion Otaria flavescens. How their reproductive ecology is affected by stochastic and long-term environmental changes in prey availability is unknown. However, studies of other pinniped species suggest that severe fluctuations in prey may cause high mortality and reproductive failure, and directly affect their population dynamics. 
From 1997 to 2002, we investigated how changes in prey abundance affected the reproductive success of South American sea lions. We were particularly interested in determining how this top predator copes with the highly unpredictable Peruvian marine ecosystem. Our study encompassed one major El Niño and one La Niña event. The El Niño resulted in a deep thermocline, with warm sea surface temperatures, less upwelling and a decrease in primary marine productivity (Barber \& Chavez, 1986; Trillmich, 1993; Fieldler, 2002). This caused a severe shortage of anchovy Engraulis ringes and other prey for top predators. During El Niño, anchovy (the most important prey of South American sea lions) tend to be of poor quality, in low numbers and at deeper depths than normal (Santander \& Zuzunaga, 1984; Barber \& Chavez, 1986; Arntz, Pearcy \& Trillmich, 1991; Trillmich, 1993; Alamo \& Espinoza, 1998). In contrast, shallow thermoclines, cool sea surface temperatures and high marine productivity characterize a La Niña event as occurred from 1998 to 2001 (Fieldler, 2002). This results in better feeding for pinnipeds.

South American sea lions breed during the austral summer starting in mid-December. Duration of the breeding season is affected by latitude (Campagna, 1985, Soto, 1999), with longer seasons occurring at low latitudes and shorter seasons occurring further south at high latitudes (Soto, 1999). Pregnant females give birth to a single pup and remain onshore to nurse for approximately 7 days (the perinatal period) before copulating and undertaking regular feeding trips (Campagna \& LeBoeuf, 1988). Lactation can last up to 3 years (Soto, 1999), but little is known about the timing of weaning or when dependent young may supplement their milk diet with fish. Lactating females have limited body reserves and are therefore dependent on the availability of prey near the rookery to produce the milk needed to care for their pups. Reduced prey abundance may result in a mother only acquiring enough energy to meet her metabolic needs, and may leave her unable to adequately provision her pup. Thus, a shortage of fish can directly affect pup survival.

The following study tested whether fluctuations in prey influence pup survival and the timing of births of South American sea lions. Data were obtained from 1997 to 2002 at the Ballestas Islands, Peru (Fig. 1) and span one El Niño and one La Niña event. They provide insights into how females respond when faced with food shortages and document the behavioural changes associated with prey abundance that may affect pup survival. These behavioural observations also describe the effects of the El Niño on future reproductive success.

\section{MATERIALS AND METHODS}

\section{Study site}

The Ballestas Islands $\left(13^{\circ} 44^{\prime} \mathrm{S} 76^{\circ} 24^{\prime} \mathrm{W}\right)$ are located $250 \mathrm{~km}$ south of Lima (Fig. 1). Data were collected for 27 consecutive months from January 1997 to March 1999,

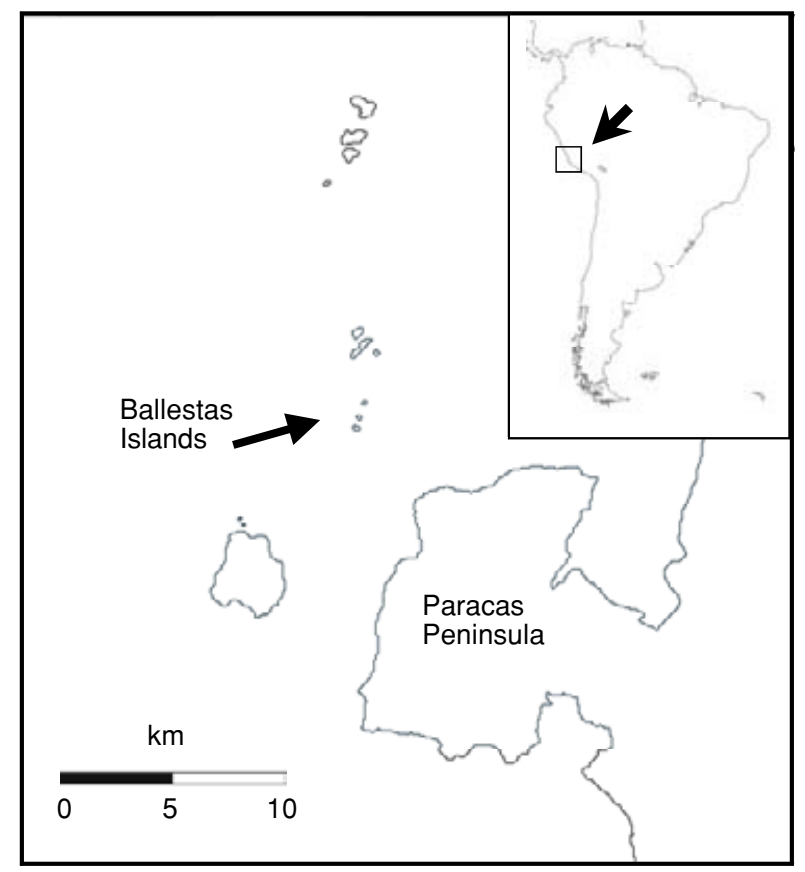

Fig. 1. The study site 'La Maternidad' located at the North Ballestas Island, Peru.

and seasonally from 4 January to 10 March for an additional 3 years (2000-2002). In all, the study encompassed 6 consecutive breeding seasons. The Ballestas Islands constitute a representative group of reproductive colonies of South American sea lions and is one of the largest breeding concentrations in Peru (Arias-Schreiber \& Rivas, 1998). These Islands are protected by the Peruvian Government as a guano bird reserve and are an important tourist attraction, where sea lions are the primary draw. The main study area, La Maternidad or 'The Maternity', is a narrow stretch of open pebble beach without pools or shaded areas. It is bounded to the north by open ocean, to the south by a rocky cliff, and by small caves to the east and west. We divided La Maternidad into 5 zones to facilitate the daily mapping of births and deaths (denotated as: Cave, $\mathrm{C} 1, \mathrm{C} 2, \mathrm{C} 3$ and $\mathrm{C} 4$ ). Conspicuous rocks marked the boundaries between zones.

\section{Births and mortality}

The number of pups born each year and the number of females onshore were determined from daily counts of pups by 2 observers during day light hours (06:00 to 18:00). Parturitions occurring at night were estimated by counting fresh placentas each morning. The estimated number of pups born each day equalled the pups born during daylight hours plus the total number of placentas seen early in the morning.

The numbers of pups that died each day was estimated from counts of fresh carcasses. Each dead pup was noted on a map to avoid double counts. Four categories of pup mortality were distinguished: male harassment, female harassment, stillborn, and unknown reasons. Unknown 
reasons were designated when a pup was found dead and could not be placed with confidence in any of the other categories. The low density of sea lions and the open flat topography of the study beach, as well as the low number of scavengers and small tides meant that few if any carcasses (or placentas) were missed.

The median dates of pupping and pup mortality were computed as the point during the breeding season when $50 \%$ of the total observed births or deaths had occurred. This was assumed to be a better measure of central tendency than the mean, because of the large differences in the start date of the breeding season among years.

\section{Food availability}

Data on abundance of prey (anchovy) was obtained from the Peruvian Marine Research Institute (IMARPE) and included anchovy biomass and monthly catches from commercial fisheries along the Peruvian coast. Anchovy biomass was estimated from hydroacoustic surveys conducted once each year (between January and April) to determine the abundance of pelagic resources along the Peruvian coast. Anchovy landings represent where the fishery was concentrated and may not have reflected all of the places where anchovy were available to sea lions. Landings were also affected by partial or total closed seasons enacted by the Peruvian Government to protect spawning anchovy. This typically occurred twice per year (normally between February-March and AugustSeptember). Duration of the closed seasons differed between years and may therefore have affected the annual amount of anchovy caught for inter-annual comparisons.

Anchovy landings data were standardized using the catch per unit effort index (CPUE) because total catches were influenced by many variable factors (e.g. number of holds, trips with catch, searching time, storage capacity in the ship). CPUE was estimated by month by IMARPE and was used to compare with pup production and mortality to test for possible relationships with prey abundance.

\section{RESULTS}

\section{Numbers of pups born and timing of births}

The number of pups born at La Maternidad fell from 1249 in 1997 to only 50 during the 1997-1998 El

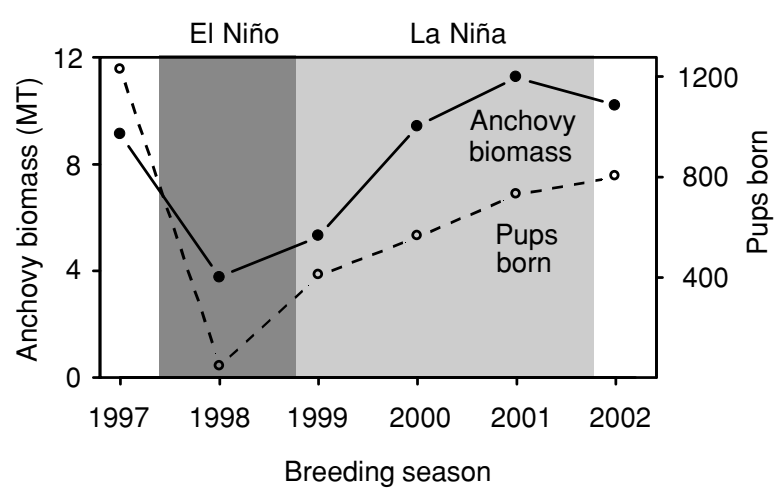

Fig. 2. Numbers of Otaria flavescens pups born (dashed line) and the estimated biomass of prey (anchovy; solid line) during the 19972002 breeding seasons. Shaded regions denote the periods of El Niño and La Niña. Anchovy biomass is measured in millions of tons (MT).

Niño (Fig. 2, Table 1). All 50 of these pups died. Pup production in subsequent years increased from 406 in 1999 to 799 in 2002. Biomass of anchovy, like pup production, dropped during the 1997-1998 El Niño, and increased over the next 4 years (Fig. 2). Birth rates (expressed as the ratio of pups born to the mean number of females counted onshore) were positively correlated with prey availability (anchovy biomass) during the breeding season (Pearson $r=0.868, p=0.025, n=6$; Fig. 3). In non-El Niño years, distributions of births varied between years (Kruskal-Wallis $\chi_{4}^{2}=65.24, p<0.001$ Fig. 4). Multiple comparison tests showed that the timings of birth before El Niño differed significantly from the 4 years that followed El Niño. Although pupping started at different dates each year, there was general synchrony in the timing and frequency of the total number of pups born (Fig. 4). Numbers of pups born were correlated with the numbers of females counted on the beach each year (Pearson $r=0.860, p=0.028, n=6$ ). As with pups, mean number of females onshore varied significantly during the study period (Kruskal-Wallis, $\chi_{5}^{2}=$ $172.5, p<0.001)$ and decreased by $90 \%$ during the 1997 1998 El Niño, and by 30\% from 1999-2002 (Table 1).

The median birth date differed among years by as much as 16 days between the earliest peak of pupping (22 January 2000) and the latest (6 February 1999) (Median test $\chi_{4}^{2}=262.9, p<0.001$; Fig. 4). Individually

Table 1. Characteristics of the breeding season of Otaria flavescens from 1997 to 2002 at the Ballestas Islands, Peru showing numbers of abortions, numbers of pups born, the percentage of pups that died, the mean number of females counted onshore, and median dates of birth and death

\begin{tabular}{|c|c|c|c|c|c|c|c|}
\hline Year & Event & Abortions & Pups born & $\begin{array}{l}\text { Pup } \\
\text { mortality (\%) }\end{array}$ & $\begin{array}{l}\text { Females } \\
\text { onshore }\end{array}$ & $\begin{array}{l}\text { Median } \\
\text { birth date }\end{array}$ & $\begin{array}{l}\text { Median } \\
\text { death date }\end{array}$ \\
\hline 1997 & & no data & 1229 & 13.3 & 885 & 31 Jan & 9 Feb \\
\hline 1998 & El Niño & $\sim 1000$ & 50 & 100 & 72 & $22 \mathrm{Jan}$ & $10 \mathrm{Feb}$ \\
\hline 1999 & La Niña & 16 & 406 & 26.4 & 548 & 6 Feb & 2 Feb \\
\hline 2000 & La Niña & no data & 561 & 32.6 & 470 & 22 Jan & 22 Jan \\
\hline 2001 & La Niña & no data & 729 & 11.4 & 458 & $23 \mathrm{Jan}$ & $20 \mathrm{Jan}$ \\
\hline 2002 & & $>100$ & 799 & 15.1 & 390 & 29 Jan & 30 Jan \\
\hline
\end{tabular}




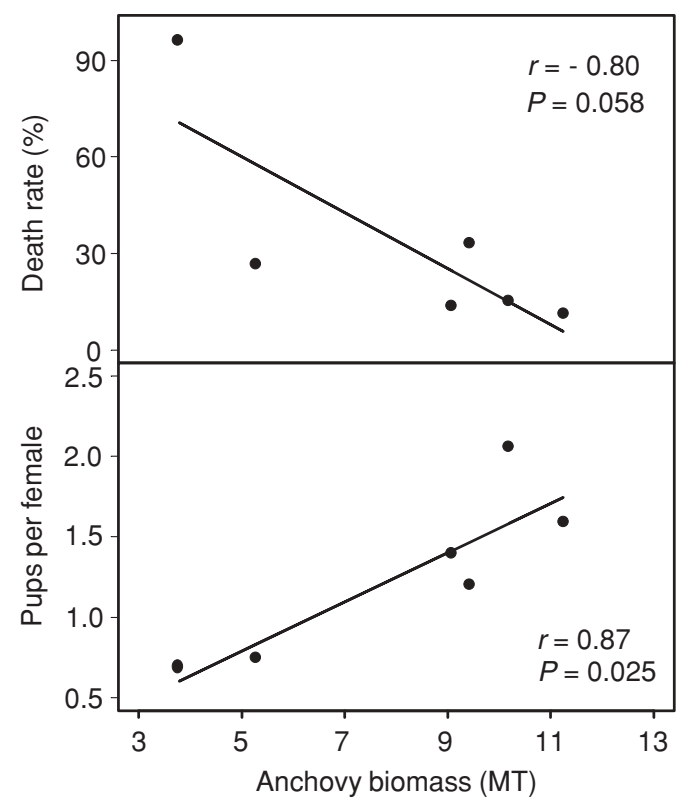

Fig. 3. Relationship between anchovy biomass (MT) and annual death rates of Otaria flavescens pups (top panel), and the numbers of pups born per females counted onshore (an index of birth rate) from 1997 to 2002 (bottom panel).

recognizable females from previous breeding seasons ( $n=8$ females) varied their pupping dates - giving birth later in the season in 1999 and earlier in 2000 and 2001. Their timing of birth was consistent with the overall pattern observed from other females. In all years the peak of mortality occurred around the peak of pupping (measured as median dates, Fig. 4).

A strong negative relationship was found between the median birth date and the assumed availability of food during the previous year (as measured by the amount of anchovy caught per unit of commercial fishing effort CPUE; Fig. 5). Median birth dates tended to be later following a year of low catches, and were earlier when catches had been high (Fig.5). Similar significant negative relationships were found between timing of birth and other indexes of CPUE such as, anchovy catch per total hours of trip (Pearson $r=-0.959, p=0.003, n=6$ ), anchovy caught per trip $(r=-0.934, p=0.006)$, catch per register of brute tonnage estimated from total hours of trips $(r=-0.918, p=0.01)$, catch per total hold $(r=-0.972, p=0.001)$ and catch per hold with fish $(r=-0.979, p=0.001)$.

Although the numbers of pups born per unit of area of the five zones of the La Maternidad beach were distributed in equal numbers in all years of study, individual females appeared to have a preference for where they gave birth. The Cave was the first zone where females gave birth each year. It differed from the other zones by having shade and lacking intraspecific attacks by subadult males.

\section{El Niño}

The 1997-1998 El Niño started in May 1997, after the breeding season ended. Abortions were first noted in late

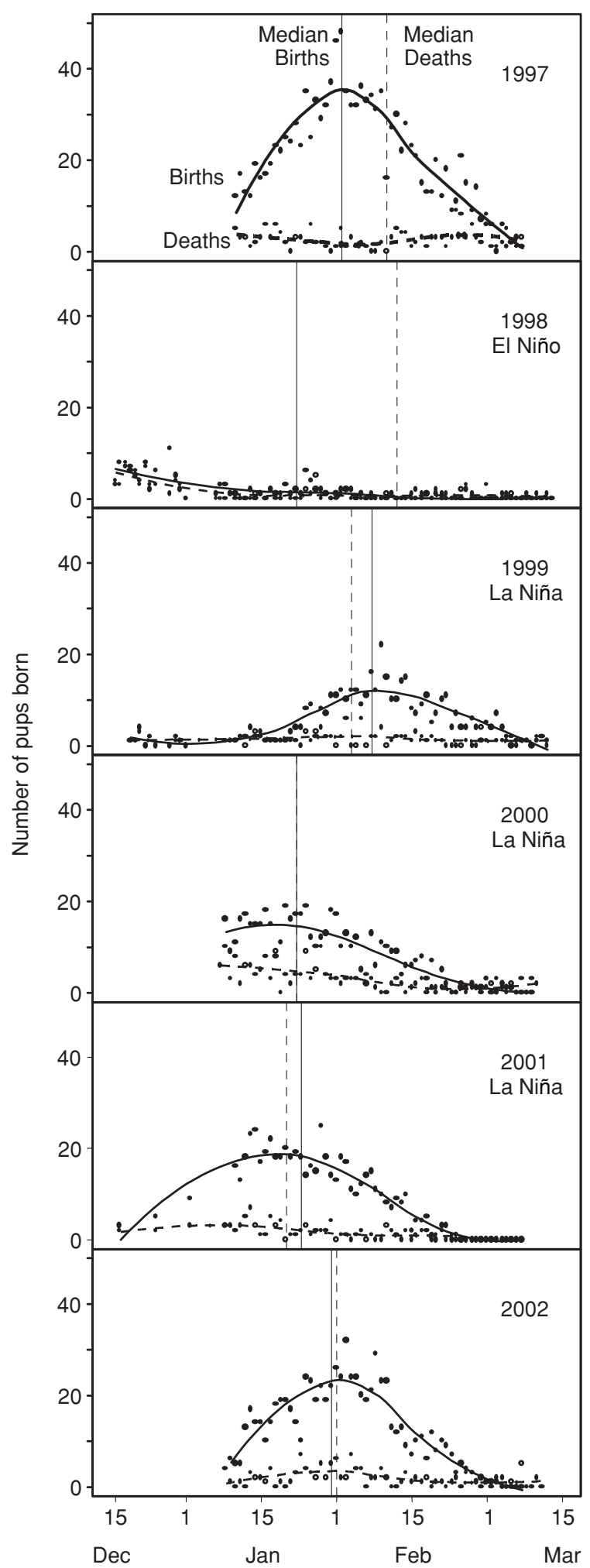

Fig. 4. Distributions of daily numbers of Otaria flavescens pups that were born or had died during the breeding season from 1997 to 2002 . Data were fit with loess curves. The vertical lines indicate the median dates of births (solid) and deaths (dashed).

July 1997, and continued progressively until late October. Foetuses seen after October were classified as premature births based on their size and their different pelage colour. 


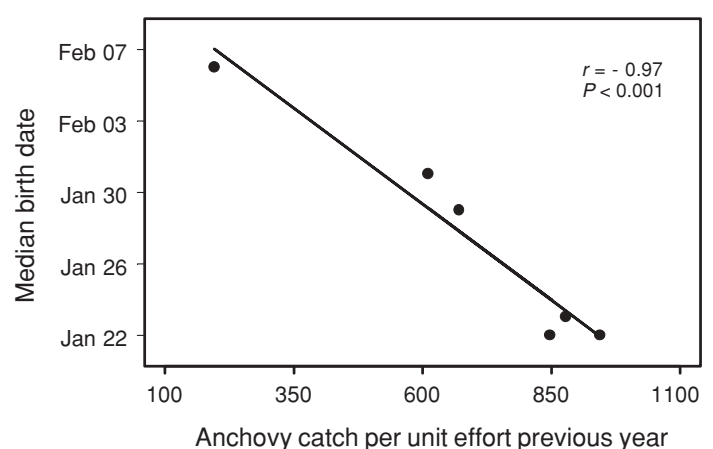

Fig. 5. The relationship between median dates of birth (1997-2002) of Otaria flavescens pups and the availability of food in the previous year (1996-2001). Food availability was assumed to be proportional to the amount of anchovy caught per unit of commercial fishing effort. Data were fit with a linear regression $(r=-0.97, P<0.01)$.

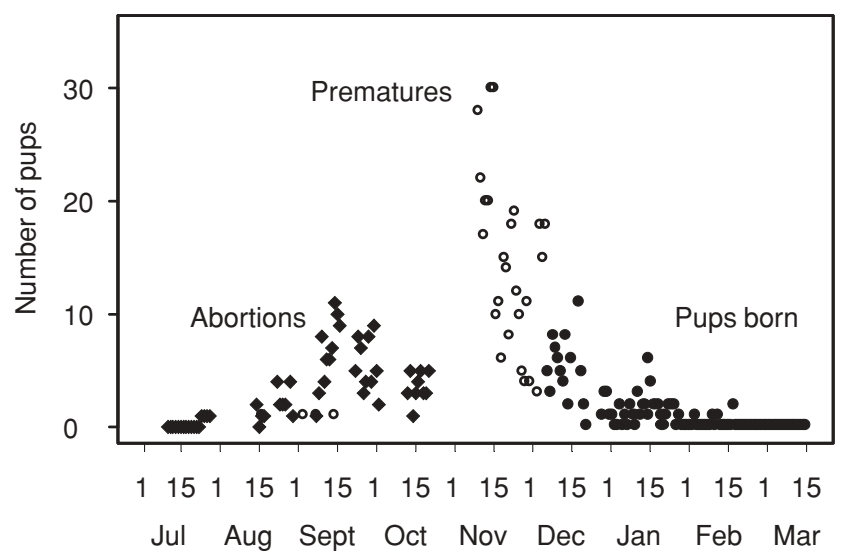

Fig. 6. Distribution of daily abortions, premature births and fullterm births of Otaria flavescens observed during the 1997-1998 El Niño.

The frequency of premature births increased dramatically in early November at a rate of approximately 25 per day (Julian Uribe, pers. comm.) and peaked in mid-November (Fig. 6). In all, 175 abortions and 440 premature births were observed in 1998 during the non-breeding season. Assuming 25 premature births occurred on each of the 15 days we were not present, the total number of reproductive failures numbered about 1000 . High numbers of premature pups occurred at other rookeries in Peru during the El Niño, but no systematic data of the daily rate are available.

During the 1997-1998 El Niño breeding season (January-March), only 50 pups were born $(\sim 5 \%$ of the expected total pup production) (Fig. 4). Most of these were abandoned on the beach by their mothers. Marked females that abandoned their pups were observed on different rookeries and islands as far as $250 \mathrm{~km}$ south of our study site.

In contrast to the El Niño, only 16 premature births were noted during La Niña (April-November 1998). A second
El Niño of moderate intensity occurred in 2002-2003 after we had completed our intensive observations, and again resulted in an increase in abortions (at a rate of three per day between September and November 2002). No data were recorded before or after these months. Sexually mature females in 2002 appeared to be older, in better condition, and were probably more experienced than those seen at the peak of the first El Niño (inferred by their large size). There was no evidence from other rookeries that massive abortions occurred during the 2002-2003 El Niño as seen during the 1997-1998 El Niño.

Unusual maternal behaviours were observed during the 1997-1998 El Niño when a few females $(n=5)$ abandoned the beach as they were giving birth (the pups were emerging from the mothers as they entered the water). Parturition was probably completed at sea where the pups would have drowned. A number of other females arrived on the beach $(n=28)$ with newborns in their mouths. Of these 28 pups, $39 \%$ were alive $(n=11), 46 \%$ were dead $(n=13)$, and $7 \%$ were undetermined $(n=2)$. The umbilical cord and remains of placenta were seen in all cases. Two other females arrived at the beach without a pup, but expelled their placenta minutes later. A few other females took their pups to sea after giving birth $(n=7$ live pups, and $n=1$ dead pup).

During the 1998 El Niño breeding season, yearlings were observed trying to take milk from unrelated females $(n=17)$. Only six were successful $(35 \%)$ and three of the $17(18 \%)$ were injured by the adult females. All individuals (yearlings and adult females) were visibly emaciated. Pups were also observed trying to take milk $(n=39)$, but only $39 \%$ of them were successful. Pups were frequently rejected by other females, and 5\% were injured through their persistence. Pups, in groups of up to four individuals, were observed following mothers arriving on the beach and trying to take milk. Although not quantified, pups were also seen trying to take milk during the 2002 2003 El Niño breeding season. However, the frequencies appeared to be much lower than during the 1997-1998 El Niño. Such behaviour was not observed in other years. Pups appeared to be undernourished during the 20022003 El Niño breeding season as a result of infrequent nursing associated with longer maternal feeding trips $(\mathrm{K}$. Soto, pers. obs.). Pups often pursued their mothers to the shoreline as they prepared to leave on a foraging trip, and tried unsuccessfully to continue suckling.

During the 1997-1998 El Niño, 100\% mortality of yearlings and juveniles (individuals that were approximately 2 years old) occurred. No individuals from these cohorts were observed at the end of this El Niño at our study site or at other important rookeries. During the 1999 breeding season, only adults were on the beach. Overall, approximately $60 \%$ adult mortality was estimated from monthly counts before, during and after the El Niño. Although carcasses were uncommon at the study beach during the non-El Niño years, emaciated carcasses of 73 yearlings, 41 females and 35 juveniles were counted during El Niño. Yearlings were the first cohort affected by the El Niño food shortage beginning 2 months after its onset. 


\section{Pup mortality}

The number of dead pups differed significantly among years and ranged from as few as $13 \%$ before El Niño to $100 \%$ during El Niño (Chi-square test $\chi_{5}^{2}=159.8$, $p<0.001$; Fig. 7 , Table 1). Pup mortality after El Niño also differed significantly between years (Chi-square test $\left.\chi_{3}^{2}=17.6, p<0.01\right)$. There was a strong negative correlation between the death rate of pups and food availability as measured by catch per unit of effort in the commercial fishery. These indices of abundance included tons of anchovy caught per trip (Pearson $r=-0.82$, $p=0.04, n=6)$, catch per total hours of trip $(r=-0.87$, $p=0.02)$, catch per total hold $(r=-0.86, p=0.02)$, catch per hold with fish $(r=-0.84, p=0.03)$ and catch per brute tonnage register estimated from total hours of trip $(r=-0.89, p=0.01)$. There was also negative correlation between death rate and anchovy biomass during the breeding season (Pearson $r=-0.80$, $p=0.058, n=6$; Fig. 3). Higher rates of mortality were associated with lower estimates of anchovy biomass.

Pup mortality was consistently high throughout the breeding season in all years, but the distribution of deaths differed among years (Kruskal-Wallis $\chi_{4}^{2}=22.57, p<$ 0.001 ; Figs 4 \& 7). Pup mortality was independent of the number of pups born and the number of females on the beach. The only significant correlation between births and deaths occurred during the El Niño (Pearson $r=0.93, p<0.001, n=6$; Fig. 7). Pup starvation was evident during the El Niño breeding season, with only $1 \%$ of the total pups born still alive at the end of the season. One month later, only one live pup was observed on the entire beach.

The median dates of death differed by as much as 22 days between the earliest peak of pup mortality (20 January, 2000) and the latest (10 February, 1998) (Median test, $\chi_{4}^{2}=50.5, p<0.001$; Fig. 4). Numbers of pups were evenly distributed (per unit of area) over the five study zones in all years. Although the $2000 \mathrm{La}$ Niña breeding season could be considered as optimal and favourable for the reproductive success of the South American sea lions (based on the high abundance of anchovy reflected in the landings and stocks assessments), pup mortality was at its highest compared with other nonEl Niño years.

\section{Aberrant behaviour}

Pup mortality was caused by several factors that varied in importance among years. Most noteworthy was the aberrant behaviour observed particularly during the 1999 breeding season (a year after the peak of El Niño). Females in groups ranging from four to six animals were seen taking and killing newborn pups that were not their own. This behaviour accounted for 2.5 to $8.4 \%$ of total pup mortality. In most cases, females killed a pup by physical trauma while trying to keep it away from other females. Pups were also sometimes taken to sea by sub-adult males from groups of disputing females. Such behaviour was

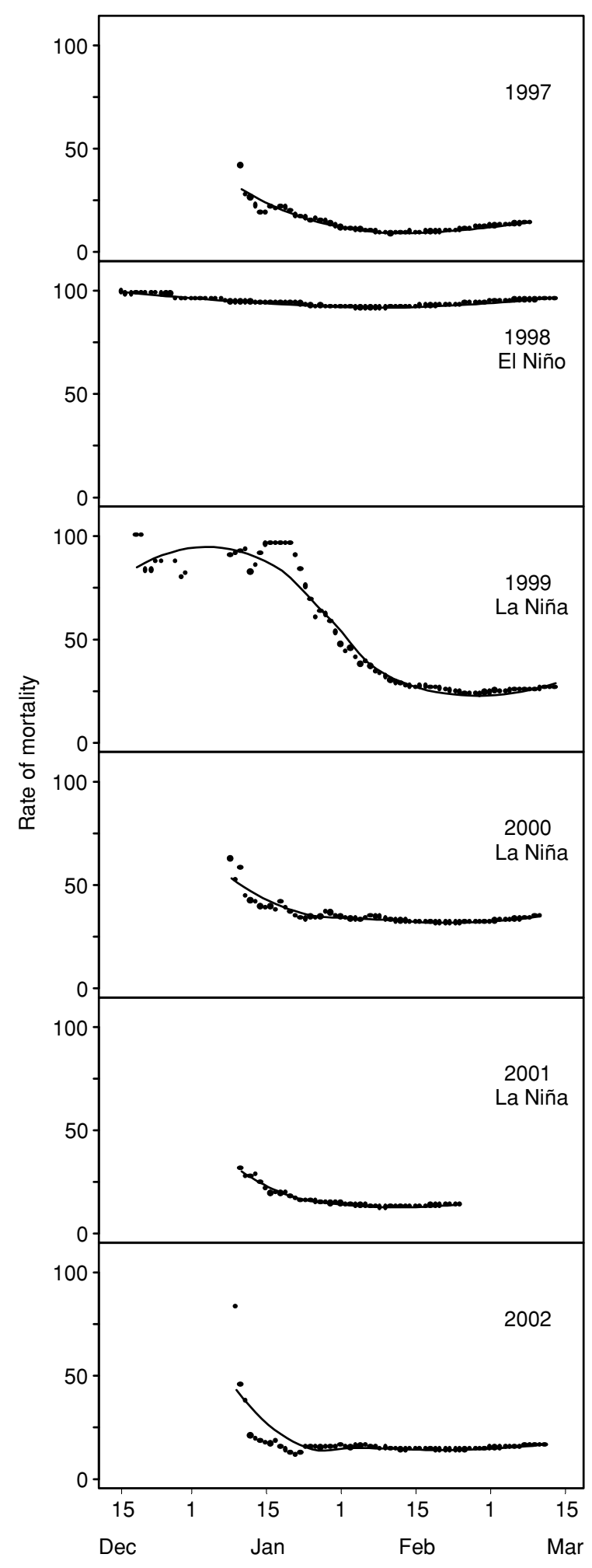

Fig. 7. Running rate of Otaria flavescens pup mortality through the breeding season from December to March (1997-2002). The rate of mortality for any given date equaled the total number of dead pups (since the first day of observation) divided by the total number of pups born over this time period.

first observed after the 1998 El Niño breeding season and continued during the rest of the study years at lower frequencies. 


\section{DISCUSSION}

An important finding of our study is that the reproductive success of South American sea lions in Peru is highly correlated with fluctuations of prey availability. The 19971998 El Niño was the strongest on record and resulted in severe short-term effects on sea lion reproductive ecology. Our study suggests that South American sea lions face highly contrasting episodes of food availability - yet can evoke strategies that enable them to adapt to stochastic changes in their ecosystem and recover under favourable environmental conditions.

\section{Pup mortality}

Inter-annual changes in the Peruvian upwelling system can significantly affect the distribution and abundance of pelagic resources and the reproductive performance of species such as the South American sea lions that depend upon them. The strongest 1997-1998 El Niño on record caused $100 \%$ of the few pups that were born that year to starve. Females returned infrequently to the beach to nurse their pups during the period of acute prey reduction (K. Soto, pers. obs.), and probably did not have sufficient milk to nourish their pups adequately. The acute food shortage resulted in high adult mortality (approximately $60 \%$ ) and the loss of entire young cohorts (ages 0,1 and 2 years old). High numbers of carcasses recorded during annual censuses along the Peruvian coast confirmed the high mortality rates (M. Arias-Schreiber, pers. obs.). Stillbirths were observed in low numbers and accounted for an average of $2.3 \%$ of the total mortality in all years.

In contrast to El Niño events, high abundance of prey should have been available to sea lions during the 19992001 La Niña. However, the sea lions did not appear to have fully capitalized on this change in events due to the lagged effects of the acute food shortages experienced the previous year (1997-1998 El Niño). High pup mortality recorded during the 1999 and 2000 La Niña breeding seasons may have been an indirect consequence of three different but related factors associated with short-term effects of the 1997-1998 El Niño: (1) high mortality of territorial males; (2) high incidence of intraspecific aggression; (3) aberrant female behaviour.

Only $60 \%$ of the territorial males that attempted to breed before the El Niño were alive to breed after this event. The high mortality of bulls allowed for increased intraspecific aggressions by subadult males on pups. The low numbers of territorial males present after the El Niño were insufficient to defend the relatively large breeding beach (and indirectly protect the pups). As a consequence, injuries resulting from intraspecific aggressions by the higher proportion of sub-adult males that appeared on the beach during the 2000 La Niña breeding season caused up to $50 \%$ of the total pup mortality. Aberrant female behaviour, whereby females took and killed pups that were not their own also contributed to the increased pup mortality. This aberrant behaviour seemed to be related to a low pregnancy rate and low numbers of females pupping successfully after the El Niño; and appeared to abate in subsequent years as more females successfully gave birth.

\section{Birth rates}

Our data showed that the annual ratio of pups born to the number of females present declined as anchovy biomass dropped. This ratio is effectively an index of birth rates. Most mature females return to the rookery even if they do not give birth. Thus, it appears that birth rates dropped as the availability of prey declined. Increases in pup production have been noted in some pinnipeds following a year of high food availability (see Lunn \& Boyd, 1993b). Indeed, during La Niña, we observed a doubling in the number of pups born (from 1999 to 2002). Although environmental conditions were not equal during all $\mathrm{La}$ Niña years, increased numbers of pups were born during 2000 and 2001 when food availability was higher than other years.

It is important for animals to detect environmental signals that permit them to co-ordinate or possibly adapt the physiological events of reproduction with changes in their food supply (Boyd, 1991). The 1997-1998 El Niño started soon after the breeding season ended when females would have had high energetic demands placed on them by their suckling young. Poor adult body condition probably increases the frequency with which South American sea lion abort their foetuses during years when nutritional stress becomes acute. Although the cost of producing a full-term foetus is probably small (see Winship, Trites \& Rosen, 2002), the cost of caring for a pup is not. Thus a female would have to continue to nurse a pup for 1 or more years to ensure its survival and future reproductive success. High incidence of abortions when food is scarce has been reported in species such as the South African fur seal Arctocephalus pussillus (Roux, 1997) and the California sea lion Zalophus californianus (Trillmich etal., 1991). Abortions tended to be associated with females in significantly poorer body condition compared to females that maintained pregnancies to parturition (Guinet et al., 1998).

High mortality of females during the 1997-1998 El Niño combined with low pregnancy rates probably explain the low number of births that followed the El Niño year. Although pinnipeds are capable of ovulating and conceiving when prey is restricted (Lunn \& Boyd, 1993a; Trites \& Donelly, 2003), it seems improbable that high numbers of females whose blastocysts successfully implanted, failed to carry foetuses to parturition under the favourable environmental conditions that followed the 1998 El Niño breeding season. Scarce numbers of abortions observed in our study area and other important rookeries preceding this event support this hypothesis. The reduced number of copulations and the abandonment of breeding areas we observed during the peak of the El Niño may be additional factors accounting for the low recruitment we noted after the El Niño breeding season.

Duration of the breeding cycle (from oestrus to parturition) varies according to food availability (Boyd, 
1996) and may reflect the timing of implantation (Lunn \& Boyd, 1993b). Although birth synchrony is maintained and high precision in the peak of pupping from year to year is observed in several species (Boulva, 1975; Coulson, 1981; Campagna, 1985; Duck, 1990; Majluf, 1991; Trites, 1992; Jemison \& Kelly, 2001; Pitcher et al., 2001), the South American sea lions appear to have considerable flexibility in the start and duration of their breeding season according to the availability of food. Thus, females tended to give birth later in the season after a year of low food availability, and earlier when food availability was high.

\section{Birth synchrony}

The peak of pup mortality occurred around the peak of pupping in all years. This differs from other South American sea lion rookeries on the Atlantic coast (see Campagna etal., 1992), and with other pinnipeds such as the Weddell seal (Thomas \& DeMaster, 1983). Food availability, suitable weather, and environmental cues acting together or independently may be the primary factors that determine the timing of births and enhance the reproductive success of females (Ims, 1990; Boyd, 1991; Majluf, 1992; Lunn \& Boyd, 1993b; Boness, Bowen \& Iverson, 1995; Pitcher et al., 2001). Additionally, females should give birth when the probability of offspring mortality is the lowest in order to maximize their fitness (Clutton-Brock, 1988; Trites \& Antonelis, 1994; Richter, 1999). However, the distribution of pupping dates for all breeding female South American sea lions within a season tended to be consistent across all years, despite differences in risk of losing their pups.

In general, older females tend to be more experienced and in better condition than younger females. A number of pinniped studies have documented that such females also tend to give birth earlier in the season compared with young mothers - thereby increasing the survival of their pups (Reiter, Panken \& LeBoeuf, 1981; Boyd \& McCann, 1989; Duck, 1990; York \& Scheffer, 1997). Although there is no evidence to indicate whether most dead pups belonged to young or inexperienced sea lion females before the 1997-1998 El Niño, there were few young females left alive after this event, and pup mortality remained at its highest around the peak of pupping. Although a bias towards older females giving birth earlier in the season could be expected after the El Niño, the distribution of observed births did not change. Distribution of births during the breeding season may be independent of the age of females in South American sea lions.

The closeness of the median dates of births and deaths (Fig. 4) may be related to a concomitant rise in copulations that lead to higher incidences of male-male interactions (K. Soto, pers. obs.). Although most pups died from unknown causes, intraspecific attacks were the main documented cause of direct pup mortality at the peak of births. These intraspecific attacks resulted from peripheral males that succeeded in evading the territorial males and entering the beach. Male interactions may also have contributed to mother-pup separations as have been observed elsewhere (Campagna etal., 1992; Pistorius, 2001).

The degree of polygyny appeared higher in Peru as indicated by the mean ratio of males to females (1:30) compared to the ratio (1:4) at rookeries on the Atlantic coast (see Campagna, 1985). Our study site also appears to have had a shortage of suitable territories that may have affected male behaviour and lead to intense male competition and a high incidence of intraspecific attacks on pups. An absence of pools or shady areas (necessary to reduce thermal stress due to intense solar radiation) favours territories along the water edge and restricts the number of territories. This in turn increases intraspecific competition, and favours a reproductive system where few males defend shoreline territories and have access to most copulations. This suggests that having more territories with thermoregulatory advantages besides the shoreline, would have lessened male competition and would have lowered pup mortality. Although further studies are necessary to test this hypothesis, topographies that are suitable for reproduction and enhance thermorregulation are scarce in Peru. Thus, sea lions tend to be concentrated in large numbers on relatively few rookeries that have limited access by humans.

\section{Food availability}

We found a strong relationship between reproductive success (current and future) of South American sea lions and the availability of prey in the Peruvian upwelling ecosystem. The impact that fluctuations in the availability of prey may have on the sea lion reproductive ecology will depend on the intensity and timing of such changes relative to the timing of the breeding cycle. Food shortage during El Niño events may result in higher numbers of abortions and reproductive failures in subsequent years. In contrast, high abundance of prey during La Niña can favour reproductive success and an increase in pup production.

\section{Timing of births and pup mortality}

The timings of births and pup mortality were strongly related to the interannual fluctuations in the availability of prey. Births occurred later in the season after years of low food availability and earlier in the season after a year of high food availability. Pup mortality reached its highest level when prey scarcity was acute because mothers were unable to adequately supply energy resources to their pups. Moreover, high numbers of abortions were observed during years when prey abundance appeared to be low. This may have been a physiological response of pregnant females that negated future energetic costs under adverse conditions. In contrast, when resources were abundant, the numbers of pups born rapidly increased. However, rates of pup mortality remained high during the years of high prey abundance as an indirect consequence of altered population dynamics and maternal behaviour 
caused by the previous severe food shortages that sea lions experienced during El Niño.

Global warming models predict stronger and more frequent future El Niños events along the Peruvian coast. This does not bode well for South American sea lions if the lagged aberrant behaviours associated with high adult mortality further impact their reproductive success. As such, the direct and indirect effects of the drastic and stochastic changes in the upwelling ecosystem on births and pup mortality may endanger the South American sea lions in Peru.

\section{Acknowledgments}

We wish to thank the Peruvian Marine Research Institute (IMARPE) for the logistical and field support during the entire study, and Miguel Ñiquen who provided us with unpublished data of anchovy availability in Peruvian waters. Additional logistical support was provided by IDEAWILD, and analytical support was provided through the North Pacific Universities Marine Mammal Research Consortium. The field work would not have been possible without the many people who worked with us: Roberto, Rosana, Fernando, Cynthia, Angel, Ximena, Christian, Judith, Marcelo, Francesca, Akemi and Karina. We are especially grateful to Roberto Manrique and Julian Uribe who always provided us with friendship, encouragement and logistical support. We would also like to thank Ruth Joy for assistance with data analysis; and David Rosen, Tony Sinclair, Ian Boyd, Sean Twiss, Claudio Campagna, Laura Kucey and an anonymous reviewer for constructive comments on earlier drafts of our manuscript.

\section{REFERENCES}

Alamo, A. \& Espinoza, J. (1998). Variaciones alimentarias en Engraulis ringes y otros recursos pelagicos durante InviernoPrimavera de (1997). Inf. Inst. Mar Peru 130: 45-52.

Arias-Schreiber, M. \& Rivas, C. (1998). Distribucion, tamaño y estructura de las poblaciones de lobos marinos Arctocephalus australis y Otaria byronia en el litoral peruano, en Noviembre 1996 y Marzo (1997). Inf. Prog. Ins. Mar Peru 73: 16-32.

Arntz, W., Pearcy, W. G. \& Trillmich, F. (1991). Biological consequences of the 1982-83 El Niño in the Eastern Pacific. In Pinnipeds and El Niño: responses to environmental stress: 22-42. Trillmich, F. \& Ono, K. New York: Springer-Verlag.

Barber, R. T. \& Chavez, F. P. (1986). Ocean variability in relation to living resources during the $1982-83$ El Niño. Nature 319: 279-285.

Bergallo, H. G. \& Magnusson, W. E. (1999). Effects of climate and food availability on four rodent species in southeastern Brazil. J. Mammal. 80(2): 472-486.

Bieber, C. (1998). Population dynamics, sexual activity, and reproduction failure in the fat dormouse (Myoxus glis). J. Zool. (Lond.) 244: 223-229.

Boness, D. J., Bowen, D. \& Iverson, S. I. (1995). Does male harassment of females contribute to reproductive synchronic in the grey seal by affecting maternal performance? Behav. Ecol. Sociobiol. 36: 1-10.

Boulva, J. (1975). Temporal variations in birth period and characteristics of newborn harbour seals. Rapp. P.-v. Reun. Cons. Int. Explor. Mer 169: 405-408.
Boyd, I. L. (1984). The relationship between body condition and the timing of implantation in pregnant grey seals. J. Zool. (Lond.) 203: 113-123.

Boyd, I. L. (1991). Environmental and physiological factors controlling the reproductive cycles of pinnipeds. Can. J. Zool. 69: 1135-1148.

Boyd, I. L. (1996). Individual variation in the duration of pregnancy and birth date in Antarctic fur seals: the role of environment, age, and sex of foetus. J. Mammal. 77: 124-133.

Boyd, I. L. \& McCann, T. S. (1989). Pre-natal investment in reproduction by female Antarctic fur seals. Beh. Ecol. Socio. 24: 377-385.

Boyd, I. L., Arnould, J. P. Y., Barton, T. \& Croxall, J. P. (1994). Foraging behaviour of Antarctic fur seals during periods of contrasting prey abundance. J. Anim. Ecol. 63: 703713.

Campagna, C. (1985). The breeding cycle of the Southern sea lion, Otaria byronia. Mar. Mamm. Sci. 1: 210-218.

Campagna, C., Bisioli, C., Quintana, F., Perez, F. \& Vila, A. (1992). Group breeding in sea lions: pups survive better in colonies. Anim. Behav. 43: 541-548.

Campagna, C. and Le Boeuf, B. J. (1988). Reproductive behaviour of southern sea lions. Behavior 104: 233-261.

Clutton-Brock, T. H. (1988). Reproductive success: studies of individual variation in contrasting breeding systems. Chicago: University of Chicago Press.

Costa, D. P., Croxall, J. P. \& Duck, C. D. (1989). Foraging energetics of Antarctic fur seals in relation to changes in prey availability. Ecology 70: 596-606.

Coulson, J. C. (1981). A study of the factors influencing the timing of breeding in the grey seal Halichoerus grypus. J. Zool. (Lond.) 194: 553-571.

DeLong, R. L. \& Antonelis, G. A. (1991). Impact of the 1982-1983 El Niño on the northern fur seal population at San Miguel Island, California. In Pinnipeds and El Niño: responses to environmental stress: 75-83. Trillmich, F. \& Ono, K. A. (Eds). New York, Springer-Verlag.

Duck, C. D. (1990). Annual variation in the timing of reproduction in Antarctic fur seals, Arctocephalus gazella, at Bird Island, South Georgia. J. Zool. (Lond.) 222: 103-116.

Fiedler, P. C. (2002). Environmental change in the eastern tropical Pacific Ocean: review of ENSO and decadal variability. Mar. Ecol. Prog. Ser. 244: 265-283.

Francis, J. \& Heath, C. (1991). Population abundance, pup mortality, and copulation frequency in the California sea lion in relation to the 1983 El Niño on San Nicolas Island. In Pinnipeds and El Niño: responses to environmental stress: 119-128. Trillmich, F. \& Ono, K. A. (Eds). New York: Springer-Verlag.

Georges, J.-Y., Tremblay, Y. \& Guinet, C. (2000). Seasonal diving behaviour in lactating subantarctic fur seals on Amsterdam Island. Polar Biol. 23: 59-69.

Guinet, C., Roux, J. P., Bonnet, M. \& Mison, V. (1998). Effect of body size, body mass, and body condition on reproduction of female South African fur seals (Arctocephalus pusillus) in Namibia. Can. J. Zool. 76: 1418-1424.

Heath, C. B., Ono, K. A., Boness, D. J. \& Francis, J. M. (1991). The influence of El Niño on female attendance patterns in the California sea lion. In Pinnipeds and El Niño: responses to environmental stress: 138-145. Trillmich, F. \& Ono, K. A. (Eds). New York: Springer-Verlag.

Ims, R. A. (1990). The ecology and evolution of reproductive synchrony. Trends Ecol. Evol. 5: 135-140.

Jemison, L. A. \& Kelly, B. P. (2001). Pupping phenology and demography of harbour seals (Phoca vitulina richardsi) on Tugidak Island, Alaska. Mar. Mamm. Sci. 17(3): 585600 .

Jenouvrier, S., Barbraud, C. \& Weimerskirch, H. (2003). Effects of climate variability on the temporal population dynamics of southern fulmars. J. Anim. Ecol. 74: 576-587. 
Le Boeuf, B. J. \& Reiter, J. (1991). Biological effects associated with El Niño, Southern Oscillation 1982-83, on northern elephant seals breeding at Año Nuevo, California. In Pinnipeds and El Niño: responses to environmental stress: 206-218. Trillmich, F. \& Ono, K. A. (Eds). New York: Springer-Verlag.

Lunn, N. J. \& Boyd, I. L. (1993a). Influence of maternal characteristics and environmental variation on reproduction in Antarctic fur seals. Symp. Zool. Soc. Lond. 66: 115129.

Lunn, N. J. \& Boyd, I. L. (1993b). Effects of maternal age and condition on parturition and the perinatal period of Antarctic fur seals. J. Zool. (Lond.) 229: 55-67.

Lunn, N. J., Boyd, I. L. \& Croxall, J. P. (1994). Reproductive performance of female Antarctic fur seals: the influence of age, breeding experience, environmental variation and individual quality. J. Anim. Ecol. 63: 827-840.

Majluf, P. (1991). El Niño effects on pinnipeds in Peru. In Pinnipeds and El Niño: responses to environmental stress: 55-65. Trillmich, F. \& Ono, K. A. (Eds). New York: Springer-Verlag.

Majluf, P. (1992). Timing of births and juvenile mortality in the South American fur seal in Peru. J. Zool. (Lond.) 227: 367383.

Massei, G., Genov, P. V. \& Staines, B. W. (1996). Diet, food availability and reproduction of wild boar in a Mediterranean coastal area. Acta Theriologica 41: 307-320.

McCafferty, D. J., Boyd, I. L., Walker, T. R. \& Taylor, R. I. (1998). Foraging responses of Antarctic fur seals to changes in the marine environment. Mar. Ecol. Prog. Ser. 166: 285-299.

Ono, K. A., Boness, D. J. \& Oftedal, O. T. (1987). The effect of a natural environmental disturbance on maternal investment and pup behaviour in the California sea lion. Behav. Ecol. Sociobiol. 21: 109-118.

Paredes, R. \& Zavalaga, C. (1998). Overview of the effects of El Niño 1997-1998 on Humboldt penguins and other seabirds at Punta San Juan, Peru. Penguin Conservation 11: 5-7.

Pistorius, P. A., Bester, M. N., Kirkman, S. P. \& Taylor, F. E. (2001). Pup mortality in southern elephant seals at Marion Island. Polar Biol. 24: 828-831.

Pitcher, K. W., Burkanov, V. N., Calkins, D. G., Le Boeuf, B. J., Mamaev, E. G., Merrick, R. L. \& Pendleton, G. W. (2001). Spatial and temporal variation in the timing of births of Steller sea lions. J. Mammal. 82: 1047-1053.

Pomeroy, P. \& Duck, C. (2000). Breeding performance of grey seals at the Isle of May. The effect of large-scale industrial fisheries on non-target species. Harwood, J., Final Report to DGXIV, Directorate General Fisheries of the European Commission, under Contract 95/78.

Reiter, J., Panken, K. J. \& Le Boeuf, B. J. (1981). Female competition and reproductive success in northern elephant seals. Anim. Behav. 29: 670-687.
Ritcher, T. A. (1999). The effects of density-dependent offspring mortality on the synchrony of reproduction. Evol. Ecol. 13: 167172.

Roux, J.-P. (1997). Proceedings of the International Workshop on Research and Management of Cape Fur Seals in Namibia: p. 60. Ministry of Fisheries and Marine Resources of Namibia, Swakopmund, Namibia, 24-26 June 1997.

Santander, H. \& Zuzunaga, J. S. (1984). Cambios en algunos componentes del ecosistema marino frente al Peru durante el fenomeno El Niño 1982-83. Rev. Com. Perm. Pacifico Sur 15: 311-331.

Soto, K. H. (1999). Efectos de El Niño 1997-1998 sobre el ciclo reproductivo del lobo marino chusco Otaria byronia en las islas Ballestas, Pisco, Peru. Tesis Univ. Nac. Agrar. La Molina.

Thomas, J. A. \& DeMaster, D. P. (1983). Parameters affecting survival of Weddell seal pups (Leptonychotes weddelli) to weaning. Can. J. Zool. 61: 2078-2083.

Trillmich, F. (1985). Effects of the 1982-83 El Nino on Galapagos fur seals and sea lions. Noticias de Galapagos 42.

Trillmich, F. (1993). Influence of rare ecological events on pinniped social structure and population dynamics. Symp. Zool. Soc. Lond. 66: 95-114.

Trillmich, F. and Dellinger, T. (1991). The Effects of El Niño on Galapagos Pinnipeds. In Pinnipeds and El Niño: responses to environmental stress: 66-74. Trillmich, F. \& Ono, K. A. (Eds). New York: Springer-Verlag.

Trillmich, F. \& Ono, K. A. (1991). Pinnipeds and El Niño: responses to environmental stress. Berlin: Springer-Verlag.

Trillmich, F., Ono, K. A., Costa, D. P., DeLong, R. L., Feldkamp, S. D., Francis, J. M., Gentry, R. L., Heath, C. B., Le Boeuf, B. J., Majluf, P. \& York, A. E. (1991). The effects of El Niño on pinniped populations in the eastern Pacific. In Pinnipeds and El Niño: responses to environmental stress: 247-260. Trillmich, F. \& Ono, K. A. (Eds). New York: Springer-Verlag.

Trites, A. W. (1992). Reproductive synchrony and the estimation of mean date of birth from daily counts of northern fur seal pups. Mar. Mamm. Sci. 8: 44-56.

Trites, A. W. \& Antonelis, G. A. (1994). The influence of climatic seasonality on the life cycle of the Pribilof northern fur seal. Mar. Mamm. Sci. 10: 311-324.

Trites, A. W. \& Donnelly, C. P. (2003). The decline of Steller sea lions in Alaska: a review of the nutritional stress hypothesis. Mamm. Rev. 33: 3-28.

Winship, A. J., Trites, A. W. \& Rosen, D. A. S. (2002). A bioenergetic model for estimating the food requirements of Steller sea lions (Eumetopias jubatus) in Alaska, USA. Mar. Ecol. Prog. Ser. 229: 291-312.

York, A. E. \& Scheffer, V. B. (1997). The timing of implantation in the northern fur seal, Callorhinus ursinus. J. Mammal. 78: $675-683$ 